\title{
Videos for the Global Family Business Community
}

\author{
Peter Jaskiewicz (University of Ottawa) \\ Thomas Clark (Business Families Foundation)
}

KEYWORDS: Management, Family Business, crisis management, best practice.

What does the current crisis mean for those who own and manage family businesses or who teach future family business leaders? Now more than ever, as a crisis threatens the survival of many ventures, we need to share the best thought leadership about family businesses with one another. Being able to adapt to changing environments, establish proper governance, professionalize the family firm, communicate within the family and the business, manage adversity and conflict, secure wealth and prepare the next generation have never been more important.

Although we can no longer share a physical space with colleagues, customers, or students, all of us with a deep concern for the future of family businesses can share what we know online. The Business Families Foundation (BFF) has a vast repository of relevant knowledge by expert faculty members and family business leaders. After an online guest talk by Olivier de Richoufftz, CEO of the BFF, we discussed making family business knowledge more available during this unprecedented crisis. We have selected major topics that are relevant to family enterprises during and after the crisis. These topics are also commonly taught in Bachelor, Masters and Executive Education programs around the globe.

BFF has made these videos available free of charge. These videos will bring expert advice to anyone, anyplace, anytime, anywhere. These resources are only a starting point, but we hope they can make a small difference that will help the global family business community increase their resilience and navigate these challenging times.

\section{Intrapreneurship - Rejuvenating the Business} from within

Video Title

Presented by
The Challenges of BtiligingerrairNew Brand (https://businessfamilies.com/videohome/fostering -intrapreneurship/the-challenges-of-building-anew-brand/)

Intrapreneurship atSteve Beauchesne
Beau's: The Creation of
Halcyon Barrel House
(https://businessfamilies.
com/videohome/achievin
g-generational-purpose/i
ntrapreneurship-at-beau-
s-the-creation-of-halcyon-
barrel-house/)

The Future of FamilyRob Nason

Business

(https://businessfamilies.

com/videohome/fosterin

g-intrapreneurship/the-fu

ture-of-family-business/)

Innovation - Developing new solutions in an ever changing world

Video Title Presented by

Key Elements in BuildingBrandt Channing Louie

a Culture of Innovation

(https://businessfamilies.

com/videohome/fosterin

g-intrapreneurship/key-e

lements-in-building-a-

culture-of-innovation/)

Innovation and Creativityldo Aharoni
are Nurtured Through
Self Reflection

Copyright @ 2020 The Authors. Entrepreneur \& Innovation Exchange is published at EIX.org. This is an open access article under the terms of the Creative Commons Attribution-NoDerivs License, which permits use and distribution in any medium, provided the original work is properly cited and no modifications or adaptations are made. View EIX.org Authorship Terms at https://eix.org/terms 
(https://businessfamilies.com/videohome/fostering -intrapreneurship/innovation-and-creativity-arenurtured-through-self-reflection/)

Female Family Leadership - Leveraging family strengths

Video Title

\section{Presented by}

Taking on OwnershipMargaret-Jean Mannix Roles

(https://businessfamilies. com/videohome/professi onalizing-ownership/taki ng-on-ownership-roles/)

The Greatest ChallengesHeidi Vermeer-Quist

Faced by Women in Family Business Today (https://businessfamilies. com/videohome/advice-f or-a-woman-taking-on-a-I eadership-role-in-familybusiness/)

Later Generation Ownership - Ensuring continuity across generations

\section{Video Title Presented by}

How to Build YourCharles Sirois

Ownership Strategy

(https://businessfamilies.

com/videohome/professi

onalizing-ownership/how

-to-build-your-ownership-

strategy/)

The Governance andPhilippe de Gaspé Roles of OwnersBeaubien (https://businessfamilies. com/videohome/building -family-strategy/the-gove rnance-and-roles-ofowners/)

Family Relationships - Managing families and their changing dynamics over time
Video Title Presented by

Participation of In-Lawslvan Lansberg

in Family Meetings and

Processes

(https://businessfamilies. com/videohome/addressi ng-communication/partic ipation-of-in-laws-in-fami ly-meetings-anddecision-processes/)

3 Tips Every BusinessJohn Davis Family Should Follow (https://businessfamilies. com/videohome/addressi ng-communication/3-tips -every-business-familyshould-follow/)

Family Communication \& Conflict Management Ensuring That Everyone Can $\mathrm{Be}$ on the Same Page

\section{Video Title Presented by}

Next Generation LeadersBrittney Ramsay \& Breanne Creating an InclusiveRamsay

Shared Vision

(https://businessfamilies.

com/videohome/achievin

g-generational-purpose/

next-generation-leaders-

creating-an-inclusive-

shared-vision/)

Disrespect: A RootStephen Hecht

Cause of Conflict

(https://businessfamilies.

com/videohome/achievin

g-generational-purpose/

disrespect-a-root-cause-

of-conflict/)

Governance - How to Manage the Family's 
Involvement in the Business

\section{Video Title}

Presented by

Family Meetings: TheNan-b de Gaspé Beaubien Importance of Having

Structured Time for

Communication

(https://businessfamilies. com/videohome/addressi ng-communication/famil $y$-meetings-the-importan ce-of-having-structured-t ime-for-communication/)

Effective $\quad$ FamilyTaylor Family
Councils \& Family
Forums
(https://businessfamilies.
com/videohome/addressi
ng-communication/effect
ive-family-councils-and-
family-forums/)

Family Wealth Management - How to Instill Family Values in Managing Wealth

\section{Video Title}

\section{Presented by}

Teaching the Value ofDanielle Saputo Money from a Young Age (https://businessfamilies. com/videohome/achievin g-generational-purpose/t eaching-the-value-of-mo ney-from-a-young-age/)

The Challenges ofRobert Frances

\section{Measuring Success} (https://businessfamilies. com/videohome/building -family-strategy/the-chall enge-of-measuringsuccess/)

Family Philanthropy - Making a Difference to the Community

\section{Video Title Presented by}
A 5 Step Process forldo Aharoni
Developing Social
Impact
(https://businessfamilies. com/videohome/improvi ng-impact/a-5-step-proce ss-for-developing-social- impact/)

Charity vs. PhilanthropyJim Burton and the Purpose of a Family Foundation (https://businessfamilies. com/videohome/improvi ng-impact/charity-vs-phil anthropy-and-the-purpos e-of-a-familyfoundation/)

Family Office - Responsible Management of Family Wealth

\section{Video Title Presented by}

Our Family Office 100Patricia Saputo

Year Plan

(https://businessfamilies. com/videohome/building -family-strategy/our-famil y-office-100-year-plan/) 